\title{
Phosphomannose isomerase gene for selection in lettuce (Lactuca sativa L.) transformation
}

\author{
Jindřich Bř́za ${ }^{1,2 \varpi}$, Nina Růžičková2, Hana Niedermeierová1, Jana Dusbábková1 and \\ Josef Vlasák ${ }^{1}$
}

'Biology Centre of the Academy of Sciences of the Czech Republic, v.vi.., Institute of Plant Molecular Biology, České Budějovice, Czech Republic; 2University of South Bohemia, Faculty of Science, České Budějovice, Czech Republic

\begin{abstract}
A positive selection system using phosphomannose isomerase was employed for Agrobacterium tumefaciens mediated transformation of lettuce (Lactuca sativa L. var. 'Achát'). It was shown that the mannose-based selection system works very well with the lettuce genotype used, reaching up to $25 \%$ transformation efficiency on the medium with $20 \mathrm{~g} / \mathrm{L}$ mannose and $20 \mathrm{~g} / \mathrm{L}$ sucrose. The best transformation efficacy with the commonlyused kanamycin at $100 \mathrm{mg} / \mathrm{L}$ as a selection agent was $21 \%$. Southern blot analyses of thirteen chosen mannose-resistant regenerants revealed that some of them have clonal origin, about one-half harbour a single TDNA copy and one plant contains an incomplete T-DNA segment with only the left part of T-DNA with the pmi gene present in the genomic DNA. The following Northern analysis showed transcriptional activity of the introduced pmi gene in all plants analysed with very high differences in the level of pmi specific mRNA. The results demonstrate that both mannose and kanamycin provide comparable transformation efficiencies in our lettuce genotype. An alternative selection method with mannose as a selection agent is now available for lettuce transgenosis.
\end{abstract}

Keywords: phosphomannose isomerase, pmi, npt II, Lactuca sativa, kanamycin, transformation efficiency

Received: 30 January, 2010; revised: 25 February, 2010; accepted: 11 March, 2010; available on-line: 16 March, 2010

\section{INTRODUCTION}

When Fraley and coworkers published in 1983 the first successful transformation of a plant genome with foreign genes, a new key tool for basic plant research as well as applied research was created. It was shown that genes for antibiotic resistance or herbicide tolerance could be used as reliable markers for transgenic tissue selection. Such traditional and frequently used plant selectable marker genes are, for example, the nptII gene granting resistance to aminoglycoside antibiotics like kanamycin, neomycin, paromomycin and G-418, the $h p h$ gene conferring hygromycin B resistance, or the bialaphos resistance genes bar and pat providing resistance to herbicides with phosphinothricin active compound. Unfortunately, antibiotic resistance markers are not appropriate for monocots (Wilmink \& Dons, 1993) and other plant species, and they are not accepted by the public. The same is true for the markers based on herbicide resistance. In addition, the traditional selective agents often adversely affect the transformed plant cells, bringing about a decrease in the regeneration of transformed cells by the accumulation of toxic compounds from killed, non-transformed cells (Hansen \& Wright, 1999). Also, for the introduction of several genes into a single transgenic plant, the development of further types of selectable markers is desirable.

Up to now, a number of marker genes have been employed for the development of alternative selection systems that avoid the use of either antibiotics or herbicides (Sundar \& Sakthivel, 2008). Such promising alternative systems were developed by Joersbo and Okkels (1996) with the selectable agent benzyladenine N-3-glucuronide, Haldrup et al. (1998) with D-xylose, Kunze et al. (2001) with 2-deoxyglucose, Erikson et al. (2004) with D-amino acids, Erikson et al. (2005) with D-serine, Yamada et al. (2005) and Hsiao et al. (2007) with 5-methyltrytophan. Also, You et al. (2003) used a ferredoxin-like protein gene and Ebmeier et al. (2004) the Escherichia coli threonine deaminase gene as selectable markers. The mannose-based selection system with phosphomannose isomerase ( $p m i)$ gene as a selectable marker was first reported by Joersbo et al. (1998) for the transformation of sugar beet. In the following years, PMI was shown to be a useful marker in the transformation of a number of plant species such as cassava (Zhang et al., 2000), maize (Negrotto et al., 2000; Reed et al., 2001; Wright et al., 2001), Arabidopsis (Todd \& Tague, 2001), wheat (Reed et al., 2001; Wright et al., 2001), barley and watermelon (Reed et al., 2001), durum wheat (Gadaleta et al., 2006), rice (Lucca et al., 2001), sweet orange (Boscariol et al., 2003), hemp (Feeney \& Punja, 2003), pearl millet (O'Kennedy et al., 2004), tomato (Sigareva et al., 2004), bentgrass ( $\mathrm{Fu}$ et al., 2005), papaya (Zhu et al., 2005), sorghum (Gao et al., 2005), almond (Ramesh et al., 2006), onion (Aswath et al., 2006), cucumber (He et al., 2006), Chinese cabbage (Ku et al., 2006; Min et al., 2007), Torenia hybrids (Seitz et al., 2007), flax (Lamblin et al., 2007), sugarcane (Jain et al., 2007), apple (Degenhardt et al., 2007), plum (Mikhailov et al., 2007), potato (Břiza et al., 2008), and citrus (Ballester et al., 2008).

Cells of the majority of plant species take up mannose and convert it by endogenous hexokinase into mannose6-phosphate (M6P). This inhibits glycolysis, depletes the cells of inorganic phosphate and induces endonucleases to degrade DNA (Stein \& Hansen, 1999). The non-transformed plant cells starve and cease growing. In PMI-harbouring cells, however, the enzyme catalyses

凶e-mail: briza@umbr.cas.cz

Abbreviations: BAP, 6-benzylaminopurine; MS, Murashige and Skoog medium; NAA, a-naphthalene acetic acid; NPT II, neomycin phosphotransferase II; PMI, phosphomannose isomerase. 
the isomerisation of M6P to fructose-6-phosphate that is immediately metabolised through gluconeogenesis (Privalle et al., 2000) and positively influences the growth of transformed cells.

The PMI enzyme occurs in bacteria, yeast and mammals (including humans) but there are only a few plant species like soybeans and several other legumes where the enzyme has been reported to be present (Lee \& Matheson, 1984). Therefore, the PMI-based selection system employing the E. coli man A gene (Miles \& Guest, 1984) is highly versatile in plants. In addition, the selection gene product is harmless; the safety assessment for PMI (Reed et al., 2001) has revealed that purified PMI protein has no unfavourable effects in a mouse toxicity test and does not change glycoprotein profiles in PMItransformed plants.

This work reports the establishment of an efficient mannose-based selection system for the production of transgenic lettuce (Lactuca sativa L.) plants of a Czech cultivar 'Achát'.

\section{MATERIALS AND METHODS}

Plasmid construction. The pNOV2819 plant vector from Syngenta Seeds AG (Basel, Switzerland) was used as the pmi gene source. nptII gene from plasmid pGA472 (An et al., 1986) was inserted into the polylinker sequence near the right border of pNOV2819, creating the binary vector pCB3160 with two selection systems (Bříza et al., 2008). The pmi gene was driven by a short version of the cestrum yellow leaf curling virus promoter (CMPS), the nptII gene by the nopaline synthase promoter, and both genes had nopaline synthase terminator (tNOS). pCB3160 was transfected into Agrobacterium tumefaciens strain LBA4404 using the freeze-thaw method of Holsters et al. (1978) and the spectinomycin resistance gene of pNOV2819 was used for bacterial selection.

Effect of mannose on shoot formation of explants. To estimate the optimal combination of mannose/sucrose concentration in selection media, the mannose inhibition of shoot formation of explants was evaluated. Non-transformed lettuce cotyledon leaves were plated for one day on $0.75 \%$ agar complete MS medium (Murashige \& Skoog, 1962) with 3\% sucrose and $\mathrm{pH} 5.7$ and thereafter transferred on $\mathrm{R}$ media comprising MS macro-, micronutrients and vitamins, $0.93 \mathrm{mg} / \mathrm{L}$ NAA, $0.56 \mathrm{mg} / \mathrm{L} \mathrm{BAP}$, and 16 different mannose/sucrose concentrations (Table 1). Three Petri dishes, each with eight explants, were used for every mannose/sucrose combination. The dishes were cultured under a $7 \mathrm{~h}$ photoperiod of $90 \mu \mathrm{mol} / \mathrm{m}^{2}$ per s and $23^{\circ} \mathrm{C}$ for 6 weeks with medium change after 3 weeks and the number of explants with shoots, total number of shoots and shoot size was determined.

Plants and transformation. For transformation of lettuce (Lactuca sativa L. cv. 'Achát') the modified cotyledon leaves method (Michelmore et al., 1987) was used. Briefly, seeds were surface-sterilised in $70 \%(\mathrm{v} / \mathrm{v})$ ethanol for $2 \mathrm{~min}$ then immersed in diluted commercial bleach Domestos solution for $30 \mathrm{~min}$. After being washed four times (5 min each) in sterile distilled water the seeds were planted on $0.75 \%$ high gel-strength agar (Serva Electrophoresis Ltd., Heidelberg, Germany) complete MS medium supplemented with $1 \%$ sucrose and with $\mathrm{pH}$ adjusted to 5.7 before sterilisation by autoclaving. The culture conditions were as follows: $7 \mathrm{~h}$ photoperiod, irradiance of $90 \mu \mathrm{mol} / \mathrm{m}^{2}$ per s and $23^{\circ} \mathrm{C}$. Ten days later, the cotyledons were scarfed to get large wounded area and incubated with suspension of $A$. tumefaciens (adjusted to an optical density of $\mathrm{OD}_{600}$ 0.9) for $20 \mathrm{~min}$ with occasional gentle shaking. After the excess liquid of the bacterial suspension had been dried off on a sterile filter paper, the cotyledon explants were placed upside up for one day onto Petri dishes with agar $(0.75 \%)$ complete MS medium with $3 \%$ sucrose, $\mathrm{pH}$ 5.7. Thereafter, the explants were transferred to $0.75 \%$ agar selection SA medium consisting of MS macro-, micronutrients and vitamins, $0.93 \mathrm{mg} / \mathrm{L} \mathrm{NAA}, 0.56 \mathrm{mg} / \mathrm{L}$ BAP, $400 \mathrm{mg} / \mathrm{L}$ Timentin and with $100 \mathrm{mg} / \mathrm{L}$ kanamycin and $30 \mathrm{~g} / \mathrm{L}$ sucrose or different concentrations of mannose and sucrose (sucrose $20 \mathrm{~g} / \mathrm{L}+$ mannose $20 \mathrm{~g} / \mathrm{L}=\mathrm{S} 20+\mathrm{M} 20$, S25+M20, S30+M20, S20+M30, and $\mathrm{S} 30+\mathrm{M} 30)$. The dishes were placed in a growth chamber SGC097.CFX.F (Sanyo Biomedical Europe BV, Nijverheidsweg, Netherlands) with a $10 \mathrm{~h}$ photoperiod $\left(90 \mu \mathrm{mol} / \mathrm{m}^{2}\right.$ per s) and $15 / 21^{\circ} \mathrm{C}$ night/day temperature. When the calli and small shoots appeared after about 4 weeks, the explants were transferred onto regeneration agar SE medium with the same composition as SA medium except for plant hormones (BAP $1 \mathrm{mg} / \mathrm{L}$, NAA was omitted). Regenerated shoots were separated from calli and cultured on rooting SC medium (complete MS medium, $0.1 \%$ 4-morpholineethanesulfonic acid, 0.2\% gerlite, $400 \mathrm{mg} / \mathrm{L}$ Timentin and $100 \mathrm{mg} / \mathrm{L}$ kanamycin or combination of sucrose with mannose as in the corresponding SA medium).

Molecular analysis of transgenic plants. PCR assays were performed according to Klimyuk et al. (1993) using leaves from mannose or kanamycin resistant regenerated plants. NPT-1 (5'-ACGCAGGTTCTCCGGCCGCTTG-3') and NPT-2 (5'-GAAGCGGTCAGCCCAT'TCGCCG-3') primers resulted in an nptII gene fragment of $699 \mathrm{bp}$, and the presence of the pmi gene was verified using primers PMI1 (5'-ACAGCCACTCTCCATTCA-3') and PMI-2 (5'-GTTTGCCATCACTTCCAG-3') designed by Syngenta, resulting in the amplification of a $514 \mathrm{bp}$ fragment. Both PCR for $n p t I I$ and for $p m i$ were performed as duplex reactions with primers LSM-1 (5'-GAG AT'T GCA AGG GTA AAT GCC ACC-3') and LSM-2 (5'AAA ACC GGG AGA GGT TTG CAG GGG-3’) amplifying a $263 \mathrm{bp}$ fragment of lettuce gene coding for endo- $\beta$-1,4-mannanase and with PCR enhancer Master$\mathrm{Amp}^{\mathrm{TM}}$ (Epicentre, Madison, WI, USA). Amplification of the $263 \mathrm{bp}$ fragment in duplex reactions served as a positive control of PCR implementation in the tube. The PCR consisted of 35 cycles of $45 \mathrm{~s}$ denaturation at $94^{\circ} \mathrm{C}, 30 \mathrm{~s}$ annealing at $55^{\circ} \mathrm{C}$ for $n p t I I$ gene or $60^{\circ} \mathrm{C}$ for pmi and 3 min extension at $72^{\circ} \mathrm{C}$.

Genomic DNA $(15 \mu \mathrm{g})$ extracted from leaves according to Tai and Tanksley (1991) was used for Southern blot analysis. DNA was digested with BamHI restriction enzyme, electrophoresed for $16 \mathrm{~h}$ in $1 \%$ agarose gel with TBE (Tris/borate/EDTA) buffer (Sambrook et al., 1989) and transferred onto nylon Hybond- ${ }^{+}$ membrane. Hybridisations were performed according to Church and Gilbert (1984) and the membranes were probed either with the 514 bp fragment of the pmi gene or the $699 \mathrm{bp}$ of the $n p t I I$ gene probes labelled with $\left[\alpha{ }^{32} \mathrm{P}\right] \mathrm{dCTP}\left(1.11 \times 10^{8} \mathrm{MBq} / \mathrm{mmol}\right)$ using a random priming kit, Rediprime ${ }^{\mathrm{TM}}$ II (Amersham Biosciences, Little Chalfont, UK). Hybridisations were detected by autoradiography using a phosphoimager Typhoon system (Amersham Biosciences, Little Chalfont, UK) after $5 \mathrm{~h}$ exposure.

For Northern blot hybridisation, total RNA was extracted from $100 \mathrm{mg}$ of leaf tissue of selected transgen- 
otes using the RNeasy Plant Mini Kit (Qiagen, Hilden, Germany), $25 \mu \mathrm{g}$ of RNA was fractionated in a $1 \%$ agarose gel in Mops running buffer with $1.2 \mathrm{M}$ formaldehyde, transferred onto nylon Hybond- $\mathrm{N}^{+}$membrane and probed with 514 bp long pmi gene DNA probe labelled with $\left[\alpha-{ }^{32} \mathrm{P}\right] \mathrm{dCTP}$. The hybridisation buffer and temperature as well as conditions during membrane washing and detection were the same as for the Southern hybridisation.

\section{RESULTS AND DISCUSSION}

\section{Effect of mannose on shoot formation of explants}

Sixteen different combinations of mannose/sucrose in $\mathrm{R}$ media were used to evaluate the effect of mannose on the organogenesis of cotyledon explants (Table 1). After 6 weeks' cultivation we found that no explants produced shoots on media without sucrose or on medium with low sucrose $(10 \mathrm{~g} / \mathrm{L})$ but high mannose $(20 \mathrm{~g} / \mathrm{L})$ concentration. Overall it is obvious that sucrose demonstrated a protective effect against mannose - caused inhibition of the organogenesis of lettuce cotyledon leaves - the higher protection was observed for intermediate sucrose level $(20 \mathrm{~g} / \mathrm{L})$ while the total number of regenerated shoots in the media with $30 \mathrm{~g} / \mathrm{L}$ sucrose was a little lower. Similar results were described by Sigareva et al. (2004) in tomato - the addition of sucrose to the selection medium modulated the inhibitory effect of mannose on shoot formation. Analogous outcomes were also reported by Joersbo et al. (1999) testing the phytotoxic effect of mannose in the presence of four different non-toxic saccharides on the dry mass of sugar beet cotyledonary explants after 3 weeks of growth, by Wright et al. (2001) for wheat or by Negrotto et al. (2000) for maize. In 2008, we published (Bríza et al., 2008) sucrose concentration dependency of callogenesis inhibition in tomato and potato.

\section{Plant transformation}

On the basis of a previous evaluation of the inhibitory effects of mannose on callo- and organogenesis, we decided to use in transformation experiments five selection media differing in mannose/sucrose concentrations (see Materials and Methods). The total survey of results from all transformation experiments is shown in Table 2. Altogether, we obtained 68 putative transgenic plants (from 700 explants) forming roots on SC medium after selection on mannose media and 48 rooting plants (from 200 explants) after kanamycin selection. All these plants were assayed by PCR for both transgenes (Fig. 1). Some of the plants did not show the presence of transgenes, i.e. the regenerants presented escapes, or they revealed clonal origin (see below) despite our struggle to avoid collecting regenerated shoots harbouring the same transformation events by careful marking of shoot positions on the cotyledon explants. Basing on these results the transformation efficiency (expressed as the ratio of transgenic plants harbouring independent transgenic event to total number of planted explants) reached $25 \%$ in one experiment after mannose/sucrose 20/20 g/L (M20 + S20) selection and $21 \%$ using $100 \mathrm{mg} / \mathrm{L}$ kanamycin as a selection agent (Table 2). Southern hybridisations using $n p t I I$ gene-derived probe (Fig. 2A) or pmi gene-derived probe (Fig. 2B) of the thirteen assumed transgenic plants originating from a few explants after M20+S20 selection confirmed that some of them were of clonal character - three plants in lanes 4, 5 and 12, two plants in lanes 6 and 13, and two plants in lanes 10 and 11 . Out of the nine independent transposition events in Fig. 2, a complete single copy of T-DNA is present in six cases (lanes $1,4+5,7,9,10+11,12$ ) whilst two or three T-DNA copies are found in three cases (lanes $2,3,6+13)$. A comparison of blot hybridisations with both probes for the plant in lane 2 showed that the plant contained one complete T-DNA and one partial sequence consisting of the right part of the T-DNA

Table 1. Effects of mannose/sucrose on callo- and organogenesis of lettuce cotyledon explants after 6 weeks of cultivation

\begin{tabular}{|c|c|c|c|c|c|c|c|c|}
\hline Medium & $\begin{array}{l}\text { Mannose } \\
(\mathrm{g} / \mathrm{L})\end{array}$ & $\begin{array}{l}\text { Sucrose } \\
(g / L)\end{array}$ & No of explants & $\begin{array}{l}\text { Feature of } \\
\text { explants }\end{array}$ & $\begin{array}{l}\text { Feature and size of } \\
\text { calli }\end{array}$ & $\begin{array}{l}\text { Explants with } \\
\text { shoots (\%) }\end{array}$ & $\begin{array}{l}\text { Size of sho- } \\
\text { ots }(\mathrm{mm})\end{array}$ & $\begin{array}{l}\text { Number } \\
\text { of shoots }\end{array}$ \\
\hline R11 & 0 & 0 & 24 & green & none & 0 & 0 & 0 \\
\hline R12 & 5 & 0 & 23 & greenish yellow & pale green, small & 0 & 0 & 0 \\
\hline R13 & 10 & 0 & 24 & yellowish green & pale green, small & 0 & 0 & 0 \\
\hline R14 & 20 & 0 & 24 & green & none & 0 & 0 & 0 \\
\hline R21 & 0 & 10 & 24 & green & green, large & 8 & $1-2$ & 2 \\
\hline R22 & 5 & 10 & 24 & green & green, large & 50 & $3-5$ & 12 \\
\hline $\mathrm{R} 23$ & 10 & 10 & 24 & greenish yellow & pale green, medium & 17 & $4-7$ & 4 \\
\hline R24 & 20 & 10 & 23 & yellowy & brownish, small & 0 & 0 & 0 \\
\hline R31 & 0 & 20 & 16 & green & green, very large & 43 & $3-6$ & 7 \\
\hline R32 & 5 & 20 & 23 & yellowish green & brownish, large & 91 & $6-20$ & 21 \\
\hline R33 & 10 & 20 & 24 & green & yellowy, large & 75 & $6-15$ & 18 \\
\hline R34 & 20 & 20 & 24 & yellow & brownish, medium & 37 & $5-8$ & 9 \\
\hline R41 & 0 & 30 & 24 & yellowish green & pale green, large & 58 & $5-7$ & 14 \\
\hline R42 & 5 & 30 & 16 & brownish yellow & brownish, large & 56 & $4-9$ & 9 \\
\hline R43 & 10 & 30 & 23 & yellowish brown & brown, medium & 56 & $5-15$ & 13 \\
\hline R44 & 20 & 30 & 24 & yellowy & brown, medium & 33 & $5-15$ & 8 \\
\hline
\end{tabular}


$\begin{array}{llllllllllllllllll}1 & 2 & 3 & 4 & 5 & 6 & 7 & 8 & 9 & 10 & 11 & 12 & 13 & 14 & 15 & 16 & 17 & M\end{array}$

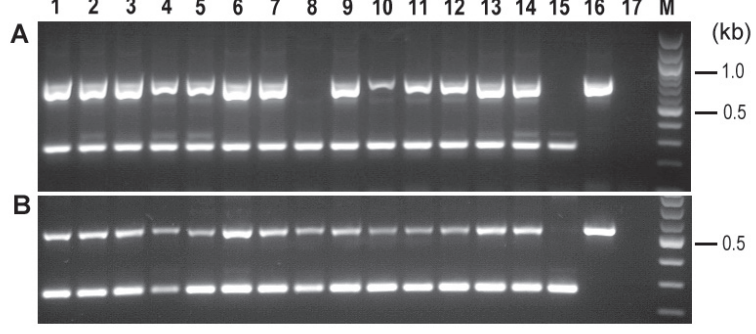

Figure 1. PCR analyses of rooted lettuce regenerants

Duplex reactions were performed by amplifying a $699 \mathrm{bp}$ fragment of the nptll gene (A) or a $514 \mathrm{bp}$ fragment of the pmi gene (B) and a $263 \mathrm{bp}$ fragment of lettuce gene coding for endo- $\beta-1,4-$ mannanase as a positive control of PCR implementation. Lanes $1-13$, randomly chosen rooting shoots from experiments using SA34 medium; lane 14, regenerated shoot after kanamycin selection; lane 15, non-transformed lettuce plant; lane 16, A. tumefaciens harbouring binary vector pCB3160; lane 17, negative control; lane M, DNA marker (100 bp ladder, NEB).

with the $n p t I I$ gene. In addition, the plant in lane 8 harboured only the left part of the T-DNA with the pmi gene but the right part was missing. PCR assays of this plant proved the presence of the pmi transgene and absence of nptII one. The ratio of single-copy/multiplecopy bearing transgenic plants is definitely different from the findings of Michelmore et al. (1987), who reported that only two out of the sixteen plants analysed appeared to have a single T-DNA insertion and other plants showed multiple independent insertions, tandem insertions or rearrangements of the T-DNA. Conversely, Lamblin et al. (2007) reported findings similar to ours when out of eight randomly chosen primary transformants five harboured a single T-DNA copy with pmi chimeric gene and three plants bore two to three copies. Control cotyledon explants (i.e., without Agrobacterium cocultivation) showed limited level of callogenesis and a very low level of organogenesis on the mannose media and none on kanamycin. If any shoots rooted (very rarely) on mannose they represented escapes without any PCR products, of course.

The highest transformation efficiency for mannose medium M20 + S20 reached $25 \%$, the average was $15 \%$. This represents a relatively high efficiency of transformation, when compared with literature data for other plant species. For example, Negrotto et al. (2000) reported in maize a $30 \%$ transformation efficiency,
Wright et al. (2001) for wheat 25\%, Feeney and Punja (2003) for hemp 31\%, Lucca et al. (2001) for rice $41 \%$, He et al. (2006) for cucumber 23\%, Aswath et al. (2006) for onion $23 \%$ or $27 \%$, Degenhardt et al. (2007) for apple up to $24 \%$, Ballester et al. (2008) for citrange $30 \%$, and Bŕiza et al. (2008) for potato up to $53 \%$. On the other hand, there are plant species where mannose-based selection of transgenic shoots does not work with such a high efficiency - $0.72 \%$ transformation efficacy was described for pearl millet (O'Kennedy et al., 2004), 0.94\% for sugar beet (Joersbo et al., 1998), $1.14 \%$ for durum wheat (Gadaleta et al., 2006), and 1.4-3\% for Chinese cabbage (Min et al., 2007). In addition, there are reports in which transformation efficiency depends on plant genotype, type of the plasmid construct or explant type (Boscariol et al., 2003; Sigareva et al., 2004). Finally, some dicotyledonous plant species like carrot, tobacco, sweet potato or leguminous crops demonstrate a substantial resistance to mannose (Sundar \& Sakthivel, 2008) and therefore a mannosebased selection system can not be employed for their successful transformation.

Northern hybridisation analysis of the same plant set as in Southern analysis with the pmi gene probe revealed the presence of pmi-specific mRNA of expected size in all transgenic plants assayed (Fig. 3). A markedly weak signal was observed in four out of thirteen mannoseselected plants because lanes 3 and 6 contained samples from the multiple-copy T-DNA plants, and lanes 2 and 8 from plants harbouring truncated T-DNA (see above).

The plasmid construct used allowed either mannoseor kanamycin-based selection. From Table 2 it is apparent that kanamycin gave a slightly lower transformation efficacy compared with mannose selection in single experiments $(21 \%$ against $25 \%)$, but the average transformation efficiency was slightly better for kanamycin - $17.5 \%$ against $15 \%$ for experiments with M20+S20 selection medium. A similar situation was reported by Lamblin et al. (2007) for flax when transformation efficacy for a mannose selection system was comparable with the kanamycin one - 3.6\% vs. 3.3\%. Our values for kanamycin are probably higher than in the work of Torres et al. (1993) where the authors described that only $6 \%$ of lettuce cotyledons gave rise to GUS-positive shoots for cv. South Bay after kanamycin selection. Curtis et al. (1994) reported genotype-independent Agrobacterium-mediated transformation of thirteen lettuce cultivars but it is not possible to derive transformation efficacy from their findings. They concluded, however, that al-

Table 2. Transformation efficiency of lettuce cotyledon explants using mannose or kanamycin (Kn, $100 \mathrm{mg} / \mathrm{L})$ selection

\begin{tabular}{|c|c|c|c|c|c|c|c|}
\hline Medium & $\begin{array}{l}\text { Mannose } \\
(\mathrm{g} / \mathrm{L})\end{array}$ & Sucrose (g/L) & $\begin{array}{l}\text { No of } \\
\text { explants }\end{array}$ & $\begin{array}{l}\text { Explants with } \\
\text { calli }(\%)\end{array}$ & $\begin{array}{l}\text { Number of } \\
\text { rooting shoots }\end{array}$ & $\begin{array}{l}\text { Number of } \\
\text { independent } \\
\text { transformants }\end{array}$ & $\begin{array}{l}\text { Transformation } \\
\text { efficiency } \\
\text { (\%) }\end{array}$ \\
\hline SA34 & 20 & 20 & 100 & 72 & 37 & 25 & 25 \\
\hline SA34 & 20 & 20 & 100 & 29 & 12 & 5 & 5 \\
\hline SA51 & 20 & 25 & 100 & 34 & 3 & 0 & 0 \\
\hline SA44 & 20 & 30 & 100 & 76 & 7 & 3 & 3 \\
\hline SA44 & 20 & 30 & 100 & 13 & 4 & 0 & 0 \\
\hline SA35 & 30 & 20 & 100 & 58 & 5 & 1 & 1 \\
\hline SA45 & 30 & 30 & 100 & 49 & 0 & 0 & 0 \\
\hline $\mathrm{SA} / \mathrm{Kn}$ & - & 30 & 100 & 59 & 30 & 21 & 21 \\
\hline $\mathrm{SA} / \mathrm{Kn}$ & - & 30 & 100 & 40 & 18 & 14 & 14 \\
\hline
\end{tabular}




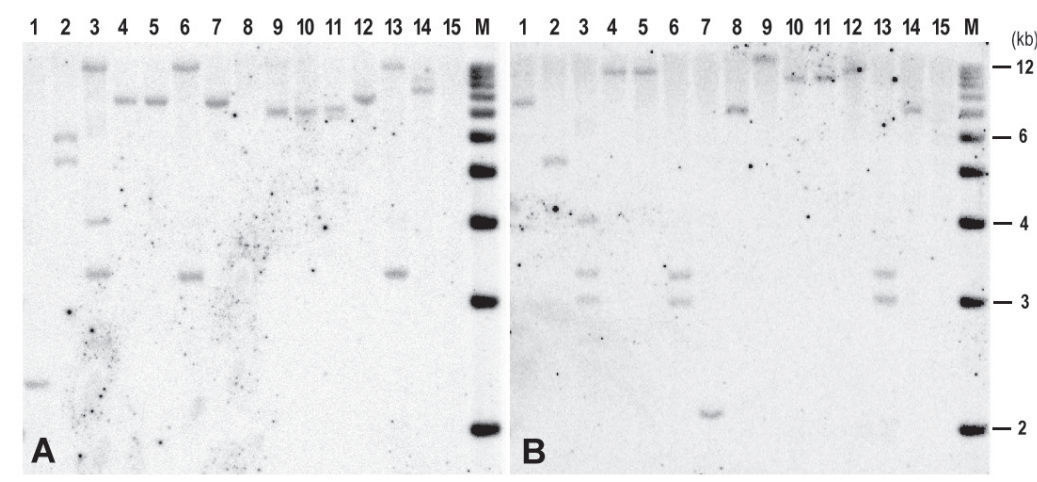

Figure 2. Southern hybridisation analyses of transformed lettuce plants bearing pCB3160 T-DNA DNA digested with BamHI was hybridised in successive steps with a $699 \mathrm{bp}$ nptll probe (A) and a $514 \mathrm{bp}$ pmi probe (B) with stripping between hybridisations. The minimal expected band size was about $2.25 \mathrm{~kb}$ for the nptll probe and $1.6 \mathrm{~kb}$ for the pmi probe. Lanes 1-15 see Fig. 1; lane M, DNA size marker ( 1 kb ladder, Gibco-BRL).

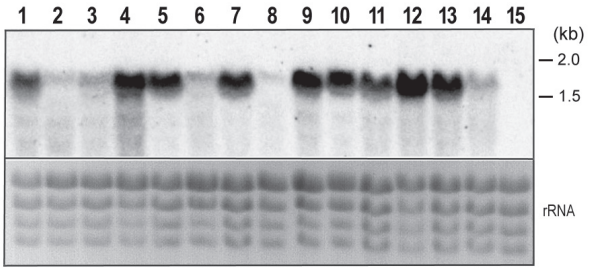

Figure 3. Northern hybridisation analysis of transformed lettuce plants with pCB3160 T-DNA

About $25 \mu \mathrm{g}$ of total RNA was probed with $514 \mathrm{bp}$ pmi gene derived probe. Lanes 1-15 see Fig. 1.

though not all cultivars could be successfully transformed at the same efficiency using a single procedure, a reliable protocol with kanamycin had been developed for routine production of transgenic lettuce plants. After that the transgenesis of lettuce using kanamycin as a selectable agent has become a standard method for different studies like introduction of a gene conferring freezing resistance (Pileggi et al., 2001), systematic silencing of tobacco nitrate reductase transgene (Dubois et al., 2005), expression of an oxalate decarboxylase gene from Flammulina sp. (Dias et al., 2006), synthesis and assembly of $E$. coli heat-labile enterotoxin B subunit (Kim et al., 2007) or for production of the Mirafiori lettuce virus resistant lettuce plants by introduction of inverted repeats of the viral coat protein gene (Kawazu et al., 2009). Another selectable transgene for use in lettuce transgenesis was, however, missing.

In conclusion, we demonstrate here for the first time that a selection system based on mannose is applicable for lettuce transformation, in particular for the cultivar 'Achát', with the transformation efficiency comparable to that obtained with the classical selectable marker gene nptII. This opens the door for advanced plant biotechnology requiring introduction of several genes into a single transgenic lettuce plant.

\section{Acknowledgements}

The authors wish to thank Syngenta Seeds AG (Switzerland), for supplying pNOV2819 plasmid and V. Tetourová and J. Mašková for excellent technical assistance.

This research was funded by CEZ: AV0Z50510513.

\section{REFERENCES}

An G, Watson BD, Chiang CC (1986) Transformation of tobacco, tomato, potato, and Arabidopsis thaliana using a binary Ti vector system. Plant Physiol 81: 301-305.
Aswath CR, Mo SY, Kim DH, Park SW (2006) Agrobacterium and biolistic transformation of onion using non-antibiotic selection marker phosphomannose isomerase. Plant Cell Rep 25: 92-99.

Ballester A, Cervera M, Peña L (2008) Evaluation of selection strategies alternative to $n p t I I$ in genetic transformation of citrus. Plant Cell Rep 27: 1005-1015.

Boscariol RL, Almeida WAB, Derbyshire MTVC, Mourao FAA, Mendes BMJ (2003) The use of the PMI/mannose selection system to recover transgenic sweet orange plants (Citrus sinensis L. Osbeck). Plant Cell Rep 22: 122-128.

Bříza J, Pavingerová D, Přikrylová P, Gazdová J, Vlasák J, Niedermeierová $\mathrm{H}$ (2008) Use of phosphomannose isomerase-based selection system for Agrobacterium-mediated transformation of tomato and potato. Biol Plant 52: 453-461.

Church GM, Gilbert W (1984) Genomic sequencing. Proc Natl Acad Sci USA 81: 1991-1995.

Curtis IS, Power JB, Blackhall NW, de Laat AMM, Davey MR (1994) Genotype-independent transformation of lettuce using Agrobacterium tumefaciens. I Exp Bot 45: 1441-1449.

Degenhardt J, Poppe A, Rösner L, Szankowski I (2007) Alternative selection systems in apple transformation. Acta Hort 738: 287-292.

Dias BBA, Cunha WG, Morais LS, Vianna GR, Rech EL, de Capdeville G, Aragão FJL (2006) Expression of an oxalate decarboxylase gene from Flammulina sp. in transgenic lettuce (Lactuca sativa) plants and resistance to Sclerotinia sclerotiorum. Plant Pathol 55: 187-193.

Dubois V, Botton E, Mever C, Rieu A, Bedu M, Maisonneuve B, Mazier M (2005) Systematic silencing of a tobacco nitrate reductase transgene in lettuce (Lactuca sativa L.). J Exp Bot 56: 2379-2388.

Ebmeier A, Allison L, Cerutti H, Clemente T (2004) Evaluation of the Escherichia coli threonine deaminase gene as a selectable marker for plant transformation. Planta 218: 751-758.

Erikson O, Hertzberg M, Nasholm T (2004) A conditional marker gene allowing both positive and negative selection in plants. Nat Biotechnol 22: 455-458.

Erikson O, Hertzberg M, Nasholm T (2005) The $d s d A$ gene from Escherichia coli provides a novel selectable marker for plant transformation. Plant Mol Biol 57: 425-433.

Feeney M, Punja ZK (2003) Tissue culture and Agrobacterium-mediated transformation of hemp (Cannabis sativa L.). In Vitro Cell Dev BiolPlant 39: 578-585.

Fraley RT, Rogers SG, Horsch RB, Sanders PR, Flick JS, Adams SP, Bittner ML, Brand LA, Fink CL, Fry JS, Galluppi GR, Goldberg SB, Hoffmann NL, Woo SC (1983) Expression of bacterial genes in plant cells. Proc Natl Acad Sci USA 80: 4803-4807.

Fu DL, Xiao YM, Muthukrishnan S, Liang GH (2005) In vivo performance of a dual genetic marker, man $A-g / p$, in transgenic bentgrass. Genome 48: 722-730.

Gadaleta A, Giancaspro A, Blechl A, Blanco A (2006) Phosphomannose isomerase, pmi, as a selectable marker gene for durum wheat transformation. I Cereal Sci 43: 31-37.

Gao ZS, Xie XJ, Ling Y, Muthukrishnan S, Liang GH (2005) Agrobacterium tumefaciens-mediated sorghum transformation using a mannose selection system. Plant Biotechnol J 3: 591-599.

Haldrup A, Petersen SG, Okkels FT (1998) The xylose isomerase gene from Thermoanaerobacterium thermosulfurogenes allows effective selection of transgenic plant cells using D-xylose as the selection agent. Plant Mol Biol 37: 287-296.

Hansen G, Wright MS (1999) Recent advances in the transformation of plants. Trends Plant Sci 4: 226-231.

He ZQ, Duan ZZ, Liang W, Chen FJ, Yao W, Liang HW, Yue CY, Sun ZX, Chen F, Dai JW (2006) Mannose selection system used for cucumber transformation. Plant Cell Rep 25: 953-958.

Holsters M, De Waele D, Depicker A, Messens E, Van Montagu M, Schell J (1978) Transfection and transformation of Agrobacterium tumefaciens. Mol Gen Genet 163: 181-187. 
Hsiao P, Sanjaya Su R-C, Teixeira da Silva JA, Chan M-T (2007) Plant native tryptophan synthase $\beta 1$ gene is a non-antibiotic selection marker for plant transformation. Planta 225: 897-906.

Jain M, Chengalrayan K, Abouzid A, Gallo M (2007) Prospecting the utility of a / MI/mannose selection system for the recovery of transgenic sugarcane (Saccharum spp. hybrid) plants. Plant Cell Rep 26: $581-590$.

Joersbo M, Okkels FT (1996) A novel principle for selection of transgenic plant cells: Positive selection. Plant Cell Rep 16: 219-221.

Joersbo M, Donaldson I, Kreiberg J, Petersen SG, Brunstedt J, Okkels FT (1998) Analysis of mannose selection used for transformation of sugar beet. Mol Breed 4: 111-117.

Joersbo M, Petersen SG, Okkels FT (1999) Parameters interacting with mannose selection employed for the production of transgenic sugar beet. Physiol Plant 105: 109-115.

Kawazu Y, Fujiyama R, Noguchi Y (2009) Transgenic resistance to Mirafiori lettuce virus in lettuce carrying inverted repeats of the viral coat protein gene. Transgenic Res 18: 113-120.

Kim T-G, Kim M-Y, Kim B-G, Kang T-J, Kim Y-S, Jang Y-S, Arntzen CJ, Yang M-S (2007) Synthesis and assembly of Escherichia coli heat-labile enterotoxin B subunit in transgenic lettuce (Lactuca sativa). Protein Expr Purif 51: 22-27.

Klimyuk VI, Carroll BJ, Thomas CM, Jones JDG (1993) Alkali treatment for rapid preparation of plant tissue for reliable PCR analysis. Plant J 3: 493-494.

Ku JJ, Park YW, Park YD (2006) A non-antibiotic selection system uses the phosphomannose-isomerase (PMI) gene for Agrobacteriummediated transformation of Chinese cabbage. J Plant Biol 49: 115122.

Kunze I, Ebneth M, Heim U, Geiger M, Sonnewald U, Herbers K (2001) 2-Deoxyglucose resistance: a novel selection marker for plant transformation. Mol Breed 7: 221-227.

Lamblin F, Aimé A, Hano C, Roussy I, Domon J-M, Van Droogenbroeck B, Lainé E (2007) The use of the phosphomannose isomerase gene as alternative selectable marker for Agrobacterium-mediated transformation of flax (Linum usitatissimum). Plant Cell Rep 26: 765772.

Lee BT, Matheson NK (1984) Phosphomannoisomerase and phosphoglucoisomerase in seeds of Cassia coluteoides and some other legumes that synthesize galactomannan. Phytochemistry 23: 983-987.

Lucca P, Ye XD, Potrykus I (2001) Effective selection and regeneration of transgenic rice plants with mannose as selective agent. Mol Breed 7: 43-49.

Michelmore R, Marsh E, Seely S, Landry B (1987) Transformation of lettuce (Lactuca sativa) mediated by Agrobacterium tumefaciens. Plant Cell Rep 6: 439-442.

Mikhailov RV, Muratova SA, Dolgov SV (2007) Production of transgenic plum plants from vegetative tissues by means of positive selection. Acta Hort 734: 129-138.

Miles JS, Guest JR (1984) Nucleotide sequence and transcriptional start point of the phosphomannose isomerase gene (manA) of Escherichia coli. Gene 32: 41-48.

Min B-W, Cho Y-N, Song M-J, Noh T-K, Kim B-K, Chae W-K, Park Y-S, Choi Y-D, Harn C-H (2007) Successful genetic transformation of Chinese cabbage using phosphomannose isomerase as a selection marker. Plant Cell Rep 26: 337-344.

Murashige TF, Skoog F (1962) A revised medium for rapid growth and bioassay with tobacco tissue cultures. Physiol Plant 15: 473-497.

Negrotto D, Jolley M, Beer S, Wenck AR, Hansen G (2000) The use of phosphomannose isomerase as a selectable marker to recover transgenic plants (Zea mays L.) via Agrobacterium transformation. Plant Cell Rep 19: 798-780.

O'Kennedy MM, Burger JT, Botha FC (2004) Pearl millet transformation system using the positive selectable marker gene phosphomannose isomerase. Plant Cell Rep 22: 684-690.
Pillegi M, Pereira AAM, dos Santos Silva J, Pillegi SAV, Verma DPS (2001) An improved method for transformation of lettuce by Agrobacterium tumefaciens with a gene that confers freezing resistance. Braz Arch Biol Technol 44: 191-196.

Privalle LS, Wright M, Reed J, Hansen G, Dawson J, Dunder EM, Chang Y-F, Powell ML, Meghji M (2000) Phosphomannose isomerase, a novel selectable plant selection system: mode of action and safety assessment. In Proceedings of the 6th international symposium on the biosafety of genetically modified organisms. Fairbairn C, Scoles G, McHughen A, eds, pp 171-178. University Extension Press, Univ. Saskatchewan, Saskatoon.

Ramesh SA, Kaiser BN, Franks T, Collins G, Sedgley M (2006) Improved methods in Agrobacterium-mediated transformation of almond using positive (mannose/pmi) or negative (kanamycin resistance) selection-based protocols. Plant Cell Rep 25: 821-828.

Reed J, Privalle L, Powell ML, Meghji M, Dawson J, Dunder E, Suttie J, Wenck A, Launis K, Kramer C, Chang YF, Hansen G, Wright M (2001) Phosphomannose isomerase: An efficient selectable marker for plant transformation. In Vitro Cell Dev Biol-Plant 37: 127-132.

Sambrook J, Fritsch EF, Maniatis T (1989) Molecular Cloning: A Laboratory Manual. 2nd edn. Cold Spring Harbor Laboratory Press, Cold Spring Harbor.

Seitz C, Bruna S, Li H, Hauser B, Forkmann G (2007) Establishment of a mannose-based selection system for the transformation of Torenia hybrids. Acta Hort 743: 139-142.

Sigareva M, Spivey R, Willits M, Kramer C, Chang YF (2004) An efficient mannose selection protocol for tomato that has no adverse effect on the ploidy level of transgenic plants. Plant Cell Rep 23: $236-245$.

Stein JC, Hansen G (1999) Mannose induces an endonuclease responsible for DNA laddering in plant cells. Plant Physiol 121: 71-79.

Sundar IK, Sakthivel N (2008) Advances in selectable marker genes for plant transformation. J Plant Physiol 165: 1698-1716.

Tai T, Tanksley S (1991) A rapid and inexpensive method for isolation of total DNA from dehydrated plant tissue. Plant Mol Biol Rep 8: 297-303.

Todd R, Tague BW (2001) Phosphomannose isomerase: A versatile selectable marker for Arabidopsis thaliana germ-line transformation. Plant Mol Biol Rep 19: 307-319.

Torres AC, Cantliffe DJ, Laughner B, Bieniek M, Nagata R, Ashraf M, Ferl RJ (1993) Stable transformation of lettuce cultivar South Bay from cotyledon explants. Plant Cell Tissue Org Cult 34: 279-285.

Wilmink A, Dons JJM (1993) Selective agents and marker genes for use in transformation of monocotyledonous plants. Plant Mol Biol Rep 11: 165-185.

Wright M, Dawson J, Dunder E, Suttie J, Reed J, Kramer C, Chang Y, Novitzky R, Wang H, Artim-Moore L (2001) Efficient biolistic transformation of maize (Zea mays L.) and wheat (Triticum aestivum L.) using the phosphomannose isomerase gene, pmi, as the selectable marker. Plant Cell Rep 20: 429-436.

Yamada T, Tozawa Y, Hasegawa H, Terakawa T, Ohkawa Y, Wakasa K (2005) Use of a feedback-insensitive $\alpha$ subunit of anthranilate synthase as a selectable marker for transformation of rice and potato. Mol Breed 14: 363-373.

You SJ, Liau CH, Huang HE, Feng TY, Prasad V, Hsiao HH, Lu JC, Chan MT (2003) Sweet pepper ferredoxin-like protein $(p f t)$ gene as a novel selection marker for orchid transformation. Planta 217: 60-65.

Zhang P, Potrykus I, Puonti-Caerlas J (2000) Efficient production of transgenic cassava using negative and positive selection. Transgenic Res 9: 405-415.

Zhu YJ, Agbayani R, McCafferty H, Albert HH, Moore PH (2005) Effective selection of transgenic papaya plants with the PMI/Man selection system. Plant Cell Rep 24: 426-432. 